\title{
Effectiveness of Examination Handling and Distribution Procedures in Curbing Malpractices in Secondary Schools in Eastern Province, Kenya
}

\author{
Eunice Kagendo Njue1, George M. Muthaa², Peter K. Muriungi ${ }^{3}$ \\ ${ }^{1}$ Principal Ikuu Girls High School, Tharaka-Nithi County, Kenya \\ ${ }^{2}$ Department of Education, Chuka University, Tharaka-Nithi County, Kenya \\ ${ }^{3}$ Department of Arts \& Humanities, Chuka University, Tharaka-Nithi County, Kenya \\ Email: gmuthaa@yahoo.com
}

Received 2 March 2014; revised 2 April 2014; accepted 9 April 2014

Copyright (C) 2014 by authors and Scientific Research Publishing Inc.

This work is licensed under the Creative Commons Attribution International License (CC BY). http://creativecommons.org/licenses/by/4.0/

\section{(c) (i) Open Access}

\begin{abstract}
Examinations provide discriminatory criteria for individuals and evaluate whether educational goals are being achieved. To guarantee equity, fair evaluation must be devoid of all malpractices. The KNEC has put in place policies aimed at reducing cases of examination malpractices; however there has been a rise in reported cases of examination malpractices with the release of every examination results. The current study sought to determine the effectiveness of the examination handling and distribution procedures in addressing the examination malpractices. A sample size of 511 subjects was involved in the study. The study was conducted using descriptive survey research design. Reliability of instruments was determined using cronbach coefficient alpha method. The study established that the management of the examinations is dominated by the male gender. Handling and distribution of examinations was blamed for examinations malpractices. The researcher recommends training for all personnel involved in the management of the examinations.
\end{abstract}

\section{Keywords}

Examinations, Handling \& Distribution, Malpractices

\section{Introduction}

Evaluation in the education process provides the means of finding out whether educational objectives are being

How to cite this paper: Njue, E. K. et al. (2014). Effectiveness of Examination Handling and Distribution Procedures in Curbing Malpractices in Secondary Schools in Eastern Province, Kenya. Creative Education, 5, 573-579. 
attained (Wheeler, 1997). According to Nevo (1995) evaluation in education has also come to be viewed by different scholars as: providing information for decision makers; the systematic investigation of the worth or merit of some object and an act of collecting systematic information regarding the nature and quality of educational objects. Evaluation should therefore be carefully designed and undertaken in a manner that it ensures fairness and objectivity on the outcome of the process.

The Kenya National Examination Council conducts the examinations, evaluates the candidates, issues mark sheets and publishes the results (Ingolo, 2009). KNEC has set rules and regulations which set equivalent conditions for the examinations so that there is fairness for all those taking the examinations (GOK, 2003). This is because examinations provide discriminatory criteria for individuals and society in the allocation of scarce opportunities in the society (Yussufu, 1985). Concerns on fairness of the examination process gave impetus to the current study.

Cheating in examinations has become a global concern. Some see it as the outcome of the "backwash effects" of examination. Examination malpractice in Kenya has attained a frightening proportion and the malpractices are sophisticated and institutionalized (Kithuka, 2004). Efforts by government administration and stakeholders in the educational sector to curtail the ugly trend have not yielded any fruit (Kithuka, 2004). The nature of examination malpractice has resulted in high turnover of incompetent graduates by institutions of higher learning (Aullo, 2004).

Due to concerns on increasing cases of malpractices the Kenya National Examinations Council introduced measures to curb the malpractices. Mwandikwa and Ocharo (2007) observe that the Kenya National Examinations Council (KNEC) instituted tough measures that not only make cheating hard, but also ensure that culprits are severely punished. While announcing the measures Wasanga (2007) observed that the council has put in place measures to curb examination irregularities and ensure the credibility of national examinations and certificates are maintained.

The climax in cheating and exam leakages by use of technology in the Kenya Certificate of Secondary Education (KCSE) has reached fever pitch in Kenya in 2010 (MOE, 2010). In 2008, the KNEC came up with a number of regulations including the development of the proposed draft legislation on the administration of examinations and banning of mobile phones in the examination room; and in 2009, the examination body reviewed its examinations timetable which saw the scrapping of examinations in the afternoons (KNEC, 2008). Additional vehicles and security personnel were dispatched to support the administrator of examination (KNEC, 2008). Moreover, examination papers were collected from KNEC headquarters a day or two before the date of the papers, thus minimizing the risk of examination leakage from months and weeks to days and hours (KNEC, 2008). This shows the government commitment to raid the examination process off the malpractice.

Despite the legal framework put in place, examination irregularities have occurred with every release of KCSE results, this is due to examination malpractices, which can be defined as a deliberate wrong doing contrary to official examination rules designed to place a candidate at an unfair advantage or disadvantage (Afolabi, 1998). No systematic studies have been done to document the effectiveness of the examinations handling and distribution procedure in curbing the examinations malpractices which was a contention of the current study.

Examinations provide discriminatory criteria for individuals and society in the allocation of scarce opportunities. In order to guarantee fair evaluation, examinations must be devoid of all forms of malpractices. Over the years, Kenyan examinations, in particular Kenya Certificate of Secondary Education Examinations have been riddled with cases of examination malpractices, in spite of policies on examination management. This study sought to investigate the effectiveness of various examination handling and distribution procedures in curbing examination malpractices.

\section{Methodology}

The study was conducted using descriptive survey research design. The study was carried out in Eastern Province; Kenya. The location was chosen because schools in the province have been affected by examination irregularities with the release of examinations every year leading to cancellation of results for affected candidates. The most notable being the cancellation of results for about 76 students in the province involved in examination malpractices in the year 2010 (MOE, 2011). A sample size of 511 respondents was used for the study. Three hundred and sixty teachers, 120 security personnel, 30 district examination officers and one provincial examination officer were sampled. One hundred and twenty schools provided the sample. Simple random sampling was 
used to ensure two schools were sampled from each district. Purposive sampling was adopted to identify head teachers, invigilators, and security officers. Questionnaires and interview schedule were used for data collection. The questionnaires were designed for collecting data from head teachers, invigilators and security officers. Structured interview schedule was used to gather information from examination officers. Reliability of the instruments was tested using cronbach coefficient alpha method. A correlation co-efficient of 0.72 and 0.71 was obtained with the teachers and security officers' questionnaires. Descriptive statistics was used to analyze both qualitative and quantitative data.

\section{Results and Discussions}

Three hundred and sixty teachers participated in the study. The researcher sought information on the gender of teacher respondents. Table 1 presents this data.

Information on Table 1 shows that majority (63.9\%) of respondents were male whereas $36.1 \%$ were female. This imbalance in gender may account for the examination malpractices since frisking of candidates can only be effectively done by invigilators of the candidates' gender. The study sought information on the teaching experience of the respondents. This data is presented in Figure 1.

Information in Figure 1 shows that most (30.0\%) of the respondents had a teaching experience of over 21 years. The information generated from the item shows that over $90 \%$ of all respondents involved in the handling and distribution of examinations had a teaching experience of more than 5 years. An item was included in the instrument which sought information on training in examination handling. The responses are presented on Table 2.

Information on Table 2 shows that majority (63.6\%) of the respondents had been trained in examination handling This is despite the responses from the examinations officers interviewed who indicated that all invigilators and head teachers were inducted on examinations handling every year before commencement of duty.

Security officers play a critical role in the management of national examinations. Demographic data of the security officers was obtained under gender, training and academic qualification. A total of 120 security personnel participated in the study. Information on the gender of the security officers was sought. Figure 2 presents

Table 1. Teachers distribution by gender.

\begin{tabular}{ccc}
\hline Gender & Number & Percentage \\
\hline Male & 230 & 63.9 \\
Female & 130 & 36.1 \\
Total & 360 & 100.0 \\
\hline
\end{tabular}

Table 2. Training on examination handling.

\begin{tabular}{cc}
\hline Response & $\%$ \\
\hline Yes & 63.6 \\
No & 36.4 \\
Total & 100.0 \\
\hline
\end{tabular}

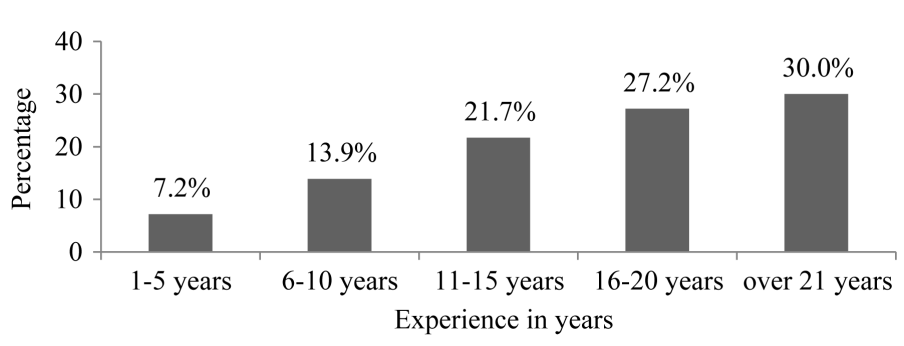

Figure 1. Teaching experience. 
the distribution of security officers by gender.

Figure 2 indicates that a large proportion (83.3\%) of security officers were males while 16.7\% were females. This shows a big disparity on the gender of security personnel involved in examination management. The study sought to establish the level of education of the security officers. The findings are presented on Table 3.

Information in Table 3 shows that Majority (68.3\%) of the respondents had a secondary school certificate, $17.5 \%$ had certificate qualification while $10.8 \%$ had diploma qualification. Only $0.8 \%$ and $2.5 \%$ of the respondents had primary certificate qualification and university degree qualification respectively. The study sought information on training of security officers on procedures that entailed examination handling and distribution. Table 4 presents the findings on induction of security officers regarding examination security procedures.

According to information on Table 4 majority (88.0\%) of the security officers had not been inducted on examination handling procedures. This implies that most of the security officers were not conversant with their role in examinations management

\section{Examination Handling and Distribution}

The objective of this study was to seek information on handling and distribution of examinations. The researcher sought information on the extent to which handling and distribution of examinations contributed to malpractices. This information is presented on Table 5 .

According to the information captured on Table 5, majority of the respondents (47.0\%) indicated that the process of examination handling and distribution contributed to examination malpractices to a great extent, $23.0 \%$ of the respondents indicated that handling and distribution contributed to a small extent to examination irregularities while $14.0 \%$ indicated that handling and distribution contributed to irregularities to a very great extent.

An item in the instrument sought an explanation from the respondents on their perceptions regarding examination handling and distribution presented on Table 5. The responses were grouped according to the recurring themes to facilitate analysis. This information is presented on Table 6.

Table 3. Academic qualification of security officers.

\begin{tabular}{ccc}
\hline Academic qualification & Frequency & Percentage \\
\hline Primary & 1 & 0.8 \\
Secondary & 82 & 68.3 \\
Certificate & 21 & 17.5 \\
Diploma & 13 & 10.8 \\
University & 3 & 2.5 \\
Total & 120 & 100.0 \\
\hline
\end{tabular}

Table 4. Security officers induction on examination security procedures.

\begin{tabular}{cccc}
\hline & \multicolumn{3}{c}{ Responses } \\
\cline { 2 - 4 } Item & $\mathrm{N}$ & Yes \% & No \% \\
\hline $\begin{array}{c}\text { Have you ever been inducted on security procedures } \\
\text { on examination handling and distribution? }\end{array}$ & 120 & 12.0 & 88.0 \\
\hline
\end{tabular}

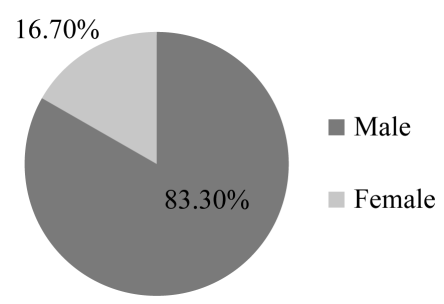

Figure 2. Distribution of security officers by gender. 
Table 5. Responses on extent of examination malpractices during handling and distribution.

\begin{tabular}{ccc}
\hline Theme & Frequency & Percentage \\
\hline Conflict of interest & 81 & 18.6 \\
Lack of professional training & 32 & 7.4 \\
Lack of integrity & 65 & 14.9 \\
Advanced technology & 72 & 16.6 \\
Financial gains & 95 & 21.8 \\
Incompetent security officers & 13 & 3.0 \\
Inadequate means of transport & 28 & 6.4 \\
Poor transport network & 27 & 6.2 \\
Insecurity & 22 & 5.1 \\
Total & 435 & 100.0 \\
\hline
\end{tabular}

Table 6. Factors contributing to malpractices in handling and distribution.

\begin{tabular}{ccc}
\hline Theme & Frequency & Percentage \\
\hline Conflict of interest & 81 & 18.6 \\
Lack of professional training & 32 & 7.4 \\
Lack of integrity & 65 & 14.9 \\
Advanced technology & 72 & 16.6 \\
Financial gains & 95 & 21.8 \\
Incompetent security officers & 13 & 3.0 \\
Inadequate means of transport & 28 & 6.4 \\
Poor transport network & 27 & 6.2 \\
Insecurity & 22 & 5.1 \\
Total & 435 & 100.0 \\
\hline
\end{tabular}

$\mathrm{n}=435$.

Findings presented on Table 6 show that $21.8 \%$ of the respondents explained that most of the personnel handling and distributing examinations engage in malpractices for financial gain. Conflict of interest was indicated as a cause of examination malpractices during distribution and handling by $18.6 \%$ of the respondents while $16.6 \%$ attributed the same to advancement in technology. Another $14.9 \%$ noted that lack of integrity was to blame for malpractice during KCSE examinations.

The study sought information on the extent to which various activities in handling and distribution contributed to examination malpractices. This information is presented in Table 7.

According to findings on Table 7 majority (26.4\%) of the respondents indicated that security at distribution centres and armories contributed to examination malpractice to a very great extent. Majority (31.7\%) of the respondents indicated that access of materials in examination centres contributed to examination malpractice to a great extent whereas $20.8 \%$ indicated very great extent.

According to findings on Table 7 majority (26.1\%) of the respondents indicated that Management of security at the distribution centres contributed to examination malpractice to a great extent. Majority (24.4\%) of the respondents indicated maintaining records of papers issued by officers managing distribution centres contributed to 
Table 7. Teachers responses on issues of examination handling and distribution.

\begin{tabular}{|c|c|c|c|c|c|}
\hline Handling and distribution practices & Very great extent & Great extent & No opinion & Small extent & No extent \\
\hline Security at distribution centres/armories & 26.4 & 23.3 & 13.3 & 20.0 & 16.9 \\
\hline $\begin{array}{l}\text { Access to examination materials in the } \\
\text { examination centres }\end{array}$ & 20.8 & 31.7 & 10.3 & 27.8 & 9.4 \\
\hline Management of security at the distribution centres & 20.3 & 26.1 & 13.3 & 23.1 & 17.2 \\
\hline $\begin{array}{l}\text { Maintaining records of papers issued by } \\
\text { officers managing distribution centres }\end{array}$ & 22.8 & 24.4 & 15.0 & 18.3 & 19.4 \\
\hline $\begin{array}{l}\text { Maintaining records of scripts received by } \\
\text { officers managing distribution centres }\end{array}$ & 27.8 & 22.2 & 13.9 & 18.6 & 17.5 \\
\hline Escorting of examination scripts & 17.5 & 14.4 & 10.8 & 25.6 & 31.7 \\
\hline Suitability of the security officers & 20.6 & 20.6 & 22.2 & 17.2 & 19.4 \\
\hline
\end{tabular}

$\mathrm{n}=360$.

examination malpractice to a great extent while $22.8 \%$ indicated very great extent. Majority (27.8\%) of the respondents indicated that maintaining records of scripts received by officers managing distribution centres contributed to examination malpractice to a very great extent and 22.2\% indicated great extent. At 31.7\%, the respondents indicated that escorting of examination scripts had no contribution to examination malpractice. Majority (22.2\%) of the respondents had no opinion on the extent to which Suitability of the security officers contributed to examination malpractice whereas $20.6 \%$ of respondents indicated that suitability of security officers contributed to examination malpractice to very great extent.

\section{Conclusions}

1) The management of the examinations in eastern province is dominated by the male gender. This is because majority of the teachers and the security officers are of the male gender. This is despite the fact that over the years the number of candidates taking examinations has almost been equal by gender.

2) The examination handling and distribution contributes to examinations malpractices since the personal used this for financial gains, had conflicting interests, and some officers lacked integrity in handling and distribution of examination materials.

3) During handling and distribution, examination malpractices mainly occurred due to poor maintenance of records of scripts received by officers managing distribution centres, inadequate security at the distribution centres/armories where examinations are stored, inadequate records of papers issued by officers managing distribution centres and by access of examination materials in the examination centres.

\section{Recommendations}

1) KNEC should Endeavour to ensure that examinations are managed by officers of both gender. This will reduce the dominance of a single gender in the management of examinations; enhance frisking of candidates and general supervision of examinations.

2) KNEC should consider training all officers to help them understand the operating regulations and policies involved in management of examinations.

3) The government should develop policies to guide the academic qualifications necessary for security offers in manning examinations of different levels.

\section{References}

Afolabi, E.R.I. (1998). Validity of Public Examinations, the Environment and Sustainable National Development. Nairobi: Cardinal Crest Ltd.

Aullo, P. A. (2004). An Investigation into Factors Contributing to Examination Irregularities in Kenya Certificate of Secondary Education (KCSE) in Eastern Province (Unpublished M.Ed Project). Nairobi: University of Nairobi.

Government of Kenya (GOK) (2003). Laws of Kenya Education Act Chapter 211. Nairobi: Government Printer. 
Ingolo, K. (2009). Maintenance of Standards in KNEC Examination Irregularities. A Paper Presented to Heads of Secondary Schools during the KESSHA Annual National Conference, Mombasa.

Kithuka, M. (2004). Educational Measurement and Evaluation. Egerton: Egerton University Press.

KNEC (2008). Examination Rules and Regularities. Nairobi: KNEC.

MOE (2011). Use of Mobile Phones during Examinations. MOE/CON/GIII/41/5. Nairobi: MOE.

MOE (2010). Kenya Certificate of Secondary Examination Results Release. Nairobi: MOE.

Mwandikwa, J., \& Ocharo, J. B. (2007). Tough Measures; Exam Cheats Put on Notice. Elimu News, 2, 12-13.

Nevo, D. (1995). School Based Evaluation: A Dialogue for Schools. New York: Elsevier Science Inc.

Wasanga, P. (2007). Maintenance of Standards in KNEC Examinations. A Paper Presented during the KESSHA Annual National Conference, Nairobi: Moi Sports Centre.

Wheeler, D. K. (1997). Curriculum Process. London: Hodder and Stoughton.

Yussufu, A. (1985). Financing and Security of National Examination. A Paper Presented at the Meeting of Institutions Responsible for Educational Assessment in East and Central Africa. Lilongwe, Malawi. 